\title{
Molecular data support the Atelurinae and Coletiniinae as sister groups: a second Lepidospora (Brinckina) species (Zygentoma: Nicoletiidae: Coletiniinae) from the Pilbara
}

\author{
Andrew Mitchell', Graeme B. Smith ${ }^{1 *}$ and Jane McRae ${ }^{2}$ \\ ${ }^{1}$ Australian Museum, 1 William St, Sydney, New South Wales 2010, Australia. \\ 2 Bennelongia Pty Ltd, 5 Bishop St, Jolimont, Western Australia 6014, Australia. \\ *Corresponding author: le_gbsmith@optusnet.com.au
}

\begin{abstract}
S and COI sequence data support the suspected closer relationship of the Atelurinae to the Coletiniinae rather than other subfamilies of the Nicoletiidae. A new species of silverfish Lepidospora (Brinckina) maceveyi sp. nov. is described from deep subterranean habitat of north-western Australia.
\end{abstract}

KEYWORDS: Thysanura, troglobite, new species

urn:Isid:zoobank.org:pub:C7BA3A25-6F8C-4A3A-8047-43A85C3CF10F

\section{INTRODUCTION}

Silverfish of the family Nicoletiidae are found in soilrelated or subterranean habitats such as caves or else found as inquilines with ants or termites. They lack eyes and pigment. Sampling of the deep subterranean habitat via mining exploration drill holes has revealed a diverse subterranean invertebrate fauna (e.g. Guzik et al., 2010) and several papers (Smith et al., 2012; Smith \& McRae, 2014) have described various nicoletiid species (Atelurinae and Subtrinemurinae) from this habitat. The first Australian representative of the subfamily Coletiniinae, Lepidospora (Brinckina) relicta Smith \& McRae (2016), was described from a drill hole in the Pilbara, with the authors noting that further species had been collected and awaited description. This paper describes a second species of Lepidospora (Brinckina) Wygodzinsky, collected from a deep subterranean habitat more than $200 \mathrm{~km}$ from the previously described species. Nuclear and mitochondrial DNA sequence data has been obtained for this new species and for five additional genera of Nicoletiidae, to consider relationships within the family.

Our understanding of nicoletiid phylogeny has evolved greatly in recent decades. Lubbock (1873) split the silverfish into two groups on the basis of the presence of scales. He included the only then-known unscaled (and eyeless) silverfish, Nicoletia phytophila Gervais, 1844, along with the Diplura in his Nicoletiadae. He included the inquiline Atelura formicaria von Heyden, 1855, among the inquiline Lepismatidae, because there was some confusion in the early days as to the presence of eyes and, no doubt, due to the tear-drop shaped body and shortened terminal filaments which seem to be a general adaptation to life as an inquiline. With more silverfish being described and more eyeless forms being discovered, a different picture began to emerge. Escherich (1905) split the silverfish into three subfamilies viz, the scaled and eyed Lepismatinae, the unscaled but also eyed Maindroniinae and the eyeless Nicoletiinae, the latter group including the genera Nicoletia, Atelura (all eyeless inquiline species which also happen to be scaled), Trinemophora Schäffer, 1897 (unscaled) and Lepidospora Escherich, 1905. This latter genus had the body shape of Nicoletia and Trinemophora but was also covered in scales. Meanwhile Silvestri, a most prolific and talented taxonomist, continued to describe numerous new species and genera of Nicoletiinae without elaborating a phylogeny for the group. Remington (1954) raised the Nicoletiinae to family level, creating a subfamily Atelurinae for the inquiline forms. Paclt (1963) in a large work based largely on literature, maintained Remington's system but revised many of the genera, which received a good deal of criticism by Wygodzinsky (1963).

Mendes (1988), while considering the Ateluridae as a separate family, split the remaining Nicoletiidae into five subfamilies viz, Nicoletiinae, Coletiniinae, Cubacubaninae, Subtrinemurinae and Protrinemurinae. Irish (1990) examined the phylogeny of the Zygentoma and could find no 
reason to exclude the Ateluridae from Nicoletiidae. Mendes (2002) analysed key characters of the Nicoletiidae and agreed with Irish. He included the Atelurinae as a subfamily within the Nicoletiidae and removed the Protrinemurinae, which he raised to family level. He also noted the close relationship between the Coletiniinae and Atelurinae which have separated coxites IX in the males (a character shared with the Lepismatidae, Maindroniidae and Tricholepidiidae) while all other Nicoletiidae subfamilies have these coxites fused into a single urosternite.

Apart from the extensive work of Espinasa with the Cubacubaninae and Nicoletiinae, very little molecular data exist at the moment to test theories on phylogeny. Espinasa and Mendes (2013) did examine the $16 \mathrm{~S}$ sequence of a species of Lepidospora (Lepidospora) from the United Arab Emirates finding the nearest relative for which they had data was a species of Australiatelura [Atelurinae] from Australia but expressed caution because of the lack of data available for other nicoletiids and the large genetic distance between the species (22.1\%).

This study offers new DNA sequence data from both nuclear and mitochondrial genes, 28S ribosomal DNA (28S) and cytochrome $c$ oxidase subunit I (COI) respectively, of the new species of Coletiniinae plus five species of Atelurinae belonging to the genera Australiatelura Mendes, 1995, Crypturelloides Smith and Veera-Singham, 2011, Proatelura Silvestri, 1916 and Pseudogastrotheus Mendes, 2003 and two species of Subtrinemurinae from the genus Trinemura Silvestri, 1905, and combines these data with COI sequences from Espinasa et al. (2007) for eleven species of Cubacubaninae from the genera Anelpistina Silvestri, 1905, Prosthecina Silvestri, 1933 and Squamigera Espinasa, 1999.

\section{SPECIMEN COLLECTION AND PREPARATION METHODS}

Specimens were collected from mining exploration drill holes using the methodology outlined in Halse \& Pearson (2014) and stored in 100\% ethanol.

The head and terminal segments were removed and held in $80 \%$ ethanol, the remaining body was then subjected to DNA extraction for one hour and then returned to $80 \%$ ethanol, after which the specimen was dissected and mounted on a single slide in Tendeiro solution. The removal of the head and posterior segment ensured that these important body parts were not degraded by DNA extraction.

A series of measurements of all specimens was undertaken according to the method described in Smith (2013). All silverfish specimens mentioned are mounted on slides and will be deposited with the Western Australian Museum, Perth.

Specimens were dissected in $80 \%$ ethanol using an Olympus SZ61 stereomicroscope and each mounted on a single slide using Tendeiro medium (Molero-Baltanás et al., 2000). Drawings were made with the aid of an Olympus CX31 binocular microscope fitted with a U-DA drawing attachment. Some twisting of macrochaetae was observed, but this was not as extensive as previously reported (Smith et al., 2012) when specimens were dissected in $100 \%$ ethanol.

Roman numerals are used to indicate abdominal segment number. The following abbreviations are also used: HW: head width (in millimetres); $\mathrm{H}+\mathrm{B}$ : head and body length (in millimetres); L/W: length to width (ratio); PI, PII, PIII: legs of pro-, meso- and metathorax respectively. The term macrochaetae refers to the larger stronger bristles, setae refers to smaller thinner bristles (usually simple) and setulae to the very small setae. Terminology for the 'segments' of the antennae, terminal filaments and ovipositor follows that explained in Smith (2015) where the term annulus will be used for each single unit of the flagellum (excluding pedicel and scape), usually a widened region carrying a single ring of setae (but occasionally with a smaller secondary ring), T-annulus for each annulus bearing a trichobothrium, interval for the group of annuli between T-annuli with the T-annulus being the most distal annulus of the interval. For the terminal filaments and ovipositor, the term division is used for each "segment" defined by a visible suture, albeit often faint.

\section{SAMPLING, DNA EXTRACTION, PCR EXTRACTION, PCR AND DNA SEQUENCING}

DNA extractions were performed using the Bioline Isolate II Genomic DNA Kit (Bioline, Eveleigh, NSW) following the manufacturers' protocol with elution volume adjusted to $50-70 \mu \mathrm{L}$. The specimens collected directly into $100 \%$ ethanol were soaked in DNA extraction buffer containing proteinase-K at room temperature for one hour. The remaining cuticle was returned to $100 \%$ ethanol and later dissected in $80 \%$ ethanol and mounted on to slides using Tendeiro medium.

Polymerase Chain Reaction (PCR) amplification of the DNA barcode region of the mitochondrial COI gene used the primers and followed the method of Mitchell (2015). For the 28S rDNA D9-D10 region, we used primers 28S_8fm and 28S_11rm, which are 5'-M13tailed versions of Machida and Knowlton's (2012) primers [28S] \#8 and [28S] \#11_RC, respectively. PCR conditions for both genes followed those reported in Mitchell (2015) for COI. PCR products were purified using ExoSAP and sequenced in both directions using ABI Big Dye Terminator v.3.1 chemistry by Macrogen Inc. (Seoul, South Korea).

\section{DNA SEQUENCE ASSEMBLY AND PHYLOGENETIC ANALYSIS}

Forward and reverse direction sequence trace files were assembled using Geneious v.10.2.6 (Kearse et al., 2012). DNA consensus sequences, sequence trace files, and specimen collection data were uploaded to BOLD (Ratnasingham \& Hebert, 2007) where they 


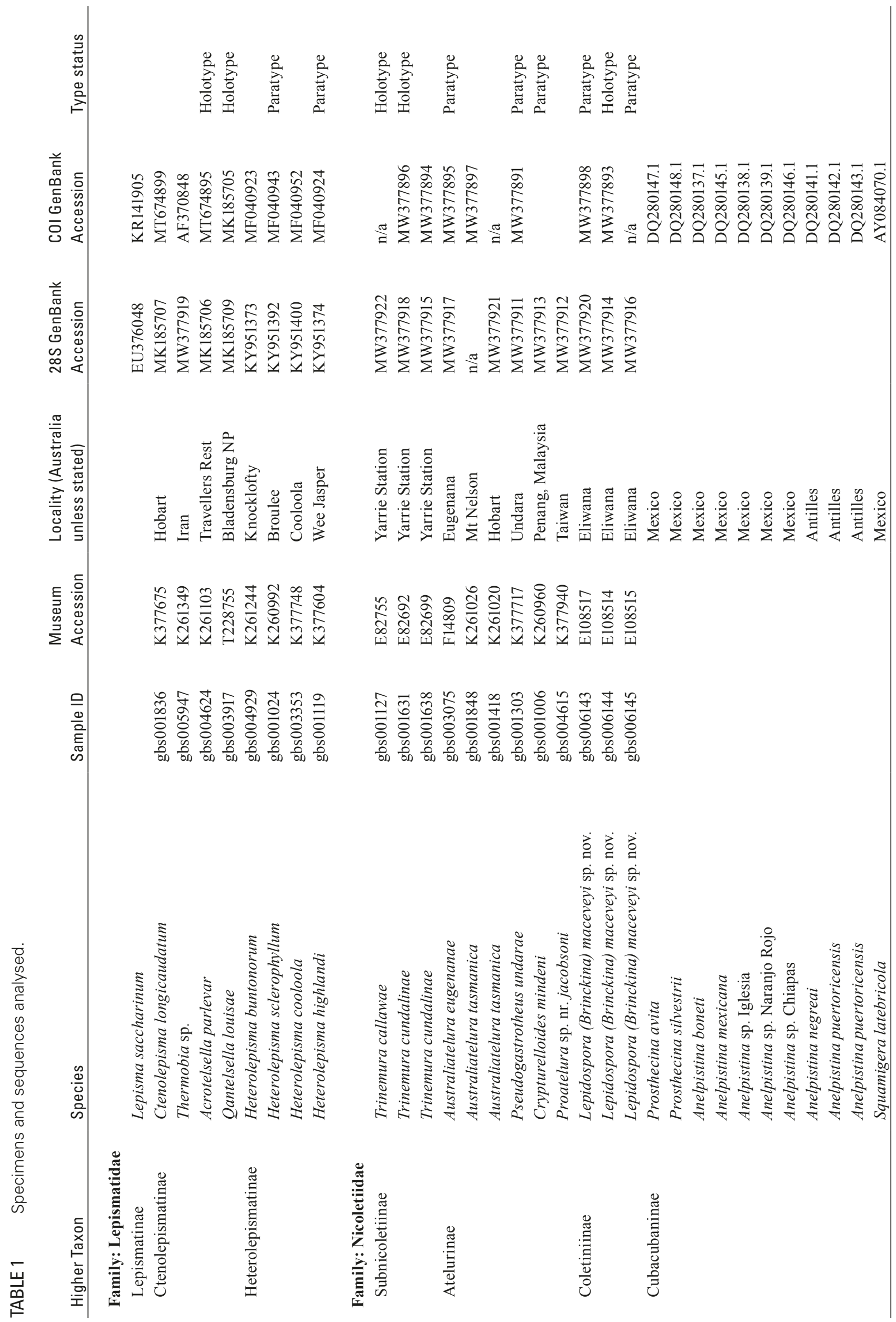


are accessible as public dataset DS-ZYLEP (dx.doi. org/10.5883/DS-ZYLEP). Sequences newly derived for this study were also deposited in GenBank (accession numbers, 28S: MW377911-MW377922, COI: MW377891-MW377898). Table 1 lists the museum, BOLD and GenBank accession numbers. Outgroups were selected from the authors' previously published studies (Smith et al., 2019) and from GenBank. COI sequences for Nicoletiidae (Cubacubaninae) were previously published by Espinasa et al. (2006). Although that study included $28 \mathrm{~S}$ sequences they were from the D3 expansion region and do not overlap with the D9 region we use in this and previous studies.

Consensus sequences were aligned by eye. Regions of the $28 \mathrm{~S}$ gene which could not be reliably aligned were excluded from the final data sets. Three data sets were constructed: 28S (20 sequences), COI (28 sequences), and all data ( 31 sequences, of which 17 were concatenated COI and 28S, 3 were $28 \mathrm{~S}$ only, and 11 were COI only).

FABOX v. 1.5 (Villesen, 2007) was used to edit sequence names. Phylogenetic analyses were performed on the CIPRES Science Gateway v3.3 (Miller et al., 2010). Partitionfinder v. 2 (Lanfear et al., 2016) was used to select a partitioning scheme and the most appropriate models for the COI and combined gene data sets. For both data sets this was two data partitions: third codon positions of COI versus all other sites, using the GTR $+\mathrm{G}$ model. Phylogenetic analyses were performed by Bayesian Inference (BI) using MrBayes 3.2.7a (Ronquist et al., 2012) and under Maximum Likelihood (ML) using RAxML v8.2.10 (Stamatakis, 2014). The BI analysis was set to run for 30 million generations, with a sample frequency of 1,000 , using two runs, setting the number of chains to four. The stopping rule was used to end the analysis when the average standard deviation of split frequencies dropped below 0.01, indicating convergence of the chains. The burnin fraction was set to 0.25 . ML analysis used the hill climbing algorithm with 1,000 rapid bootstrap replicates. All trees were rooted between the nine Lepismatidae outgroup taxa and the Nicoletiidae.

\section{RESULTS}

\section{MOLECULAR DATA}

Figure 1 shows the Bayesian tree for the data set comprising all 31 taxa. There is strong support (Bayesian posterior probability $\geq 0.9$ and ML bootstrap percentage $\geq 70$ ) for the monophyly of Nicoletiidae, and for the placement of Subnicoletiinae as sister-group to the remaining nicoletiids. There is also strong support for the monophyly of Cubacubaninae, Atopatelurini and Atelurini. Atelurinae is rendered paraphyletic by the placement of Lepidospora (Coletiniinae) as sistergroup to Atelurini, however this relationship is not strongly supported. ML analyses of this data set, and both Bayesian and ML analyses of the single gene data sets, yield closely similar results, with variations only in the relatively weakly supported relationships among Atopatelurini, Atelurini and Coletiniinae.

\section{SYSTEMATICS}

\section{Family Nicoletiidae Lubbock, 1873}

Nicoletiadae Lubbock 1873: 201.

Gymnodermata Joseph 1882: 25.

Nicoletiinae Lubbock: Escherich 1905: 36.

Nicoletiidae Lubbock: Remington 1954: 284.

\section{Subfamily Coletiniinae Mendes, 1988}

Coletiniinae Mendes, 1988: 768.

\section{Lepidospora Escherich, 1905}

Lepidospora Escherich 1905: 131.

\section{TYPE SPECIES}

Lepidospora braueri Escherich, 1905, by monotypy.

Lepidospora (Brinckina) Wygodzinsky, 1955

Lepidospora (Brinckina) Wygodzinsky 1955: 179.

\section{TYPE SPECIES}

Lepidospora (Brinckina) makapaan Wygodzinsky, 1955 , by original designation.

\section{Lepidospora (Brinckina) maceveyi Smith \& Mitchell, sp. nov.}

Figures 2-33

urn:Isid:zoobank.org:act:704DBF24-9ECD-4356-A7086D78BED95806

\section{MATERIAL EXAMINED}

Holotype

Australia: Western Australia: 1 (HW 0.83), Eliwana EW0103 $\left(22.473925^{\circ} \mathrm{S}, 116.825045^{\circ} \mathrm{E}\right), 22$ March 2019, H.L. Clark, M.K. Curran, scrape method to $22 \mathrm{~m}$ depth (WAM E108514) on single slide.

\section{Paratypes}

Australia: Western Australia: $q$ (HW 0.65), same data as holotype (WAM E108515) on single slide; ๙ (HW 0.73) Eliwana EWMS0006 (22.483954 ${ }^{\circ} \mathrm{S}$, $\left.116.865833^{\circ} \mathrm{E}\right), 21$ February 2019, J.S. Cocking, G.B. Pearson, scrape method to $30 \mathrm{~m}$ depth (WAM E108517) 


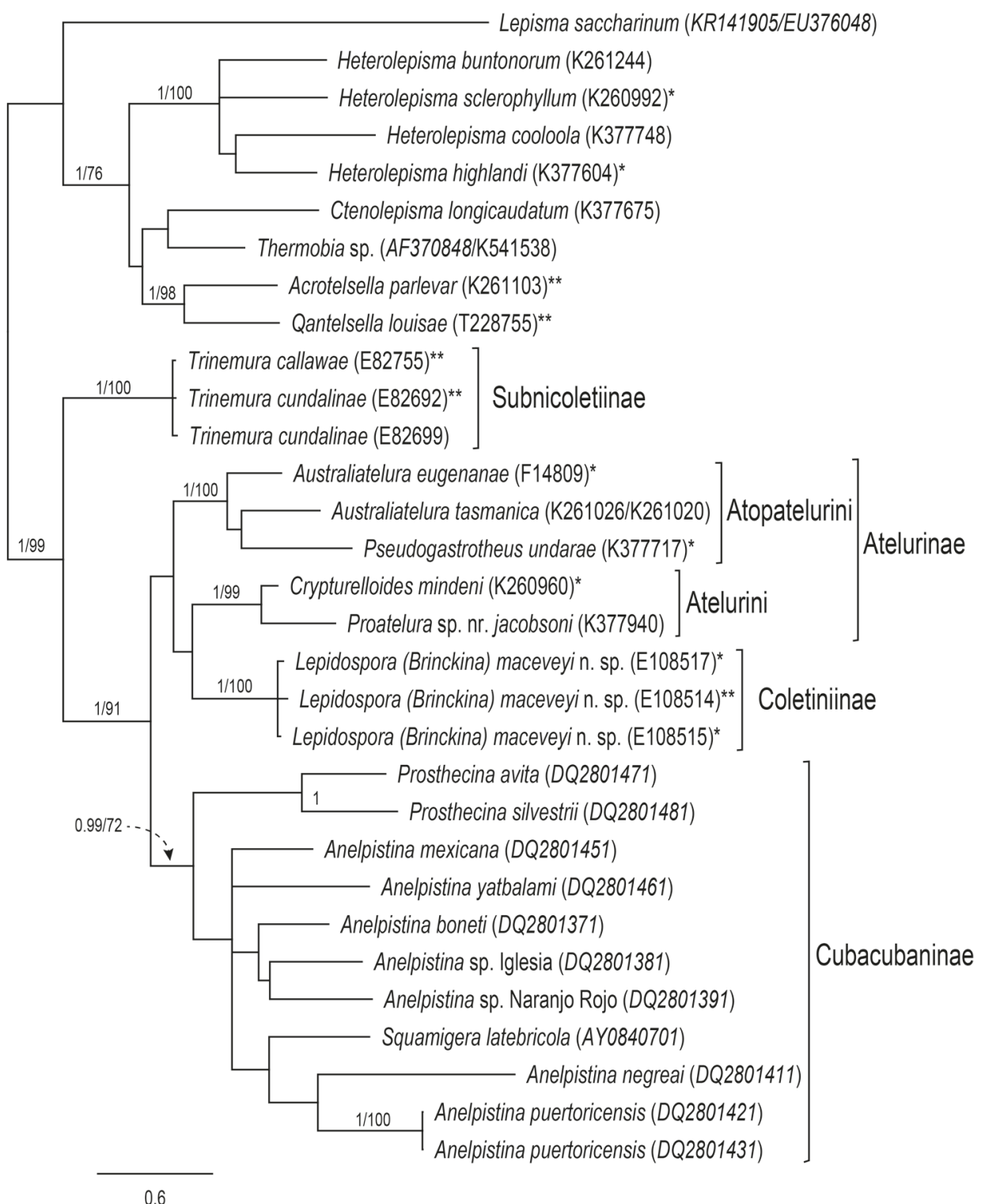

FIGURE $1 \quad$ Bayesian tree from analysis of all data (31 taxa). Numbers above branches are Bayesian posterior probability and ML bootstrap percentage, shown only if $\geq 0.9$ and 70 , respectively. Taxon names include specimens' museum accession number or GenBank accession number (in italics) for sequences derived from GenBank. For the two outgroup taxa and one ingroup taxon with $28 \mathrm{~S}$ and COI sequences derived from different specimens, two numbers are shown (** indicates holotype, ${ }^{*}$ paratype).

on single slide; $\widehat{o}$ abdomen only, Eliwana EWMS0006 FMG2628 21 February 2019, J.S. Cocking, G.B. Pearson, scrape method to $30 \mathrm{~m}$ depth (WAM E108516) on single slide.

\section{DIAGNOSIS}

Males of this species, and the closely related Lepidospora (Brinckina) relicta can be distinguished from other species of the subgenus by a combination of characters such as the shape of the apophysis and its terminal spine, the absence of longer setae over the disc of the tergites, the lack of chaetotaxy in the medial region of the posterior margin of the urotergites including urotergite IX, the downward directed posterior processes of urotergite $X$ and their $8-10+8-10$ pegs, the slightly protruding posterior margin of urosternite VIII which is straight or concave (not convex), by the presence of $2+2$ conules on the dorsal face of two of the basal divisions of the median filament and the barbed apical spines of the styli. Males of the new species can be distinguished from $L$. $(B)$. relicta by their shorter form, the wider parameres (circa five times longer than wide versus 7-10), by the very reduced number of small scattered setulae on the disc of the nota, by the obvious concave region in the middle of the posterior margin of urosternite VIII versus almost straight and the absence of strongly bifurcated macrochaetae on the ventral face of at least the division beyond that with the modified spines on the appendix dorsalis. 


\section{DESCRIPTION}

Appearance: Small, parallel-sided silverfish with elongate antennae and terminal filaments i.e. a shape typical for genus but at the shorter and wider end of the spectrum. Appearance when live unknown, probably white in colour, alcohol preserved specimens off-white. Pigment lacking.

Body length: $\mathrm{H}+\mathrm{B}$ in preserved specimens examined, up to about $5.1 \mathrm{~mm}$ (HW 0.83), thorax length up to $1.68 \mathrm{~mm}$ or about one third $\mathrm{H}+\mathrm{B}$ and width $1.05 \mathrm{~mm}$; antennae incomplete in all specimens but at least two thirds $\mathrm{H}+\mathrm{B}$; caudal filaments incomplete in all specimens, at least half as long as $\mathrm{H}+\mathrm{B}$.
Scales: Multi-radiate with about 15-20 ribs which do not extend significantly beyond the posterior end of the membranes, similar in size and shape on both dorsal (Figure 2) and ventral surfaces (Figure 3), mostly rounded apically, scales covering body but absent from head and its appendages, paramera, cerci and median dorsal appendage and probably the ovipositor (present on subgenital plate). Scales present on both coxa and femora (Figure 4), smaller than those on the body and with the ends of the ribs surpassing the margin of the membrane by about $5 \%$ of their length. A single scale is visible on the tibia of PIII of the holotype but no obvious scale insertion points can be seen and it is suspected that
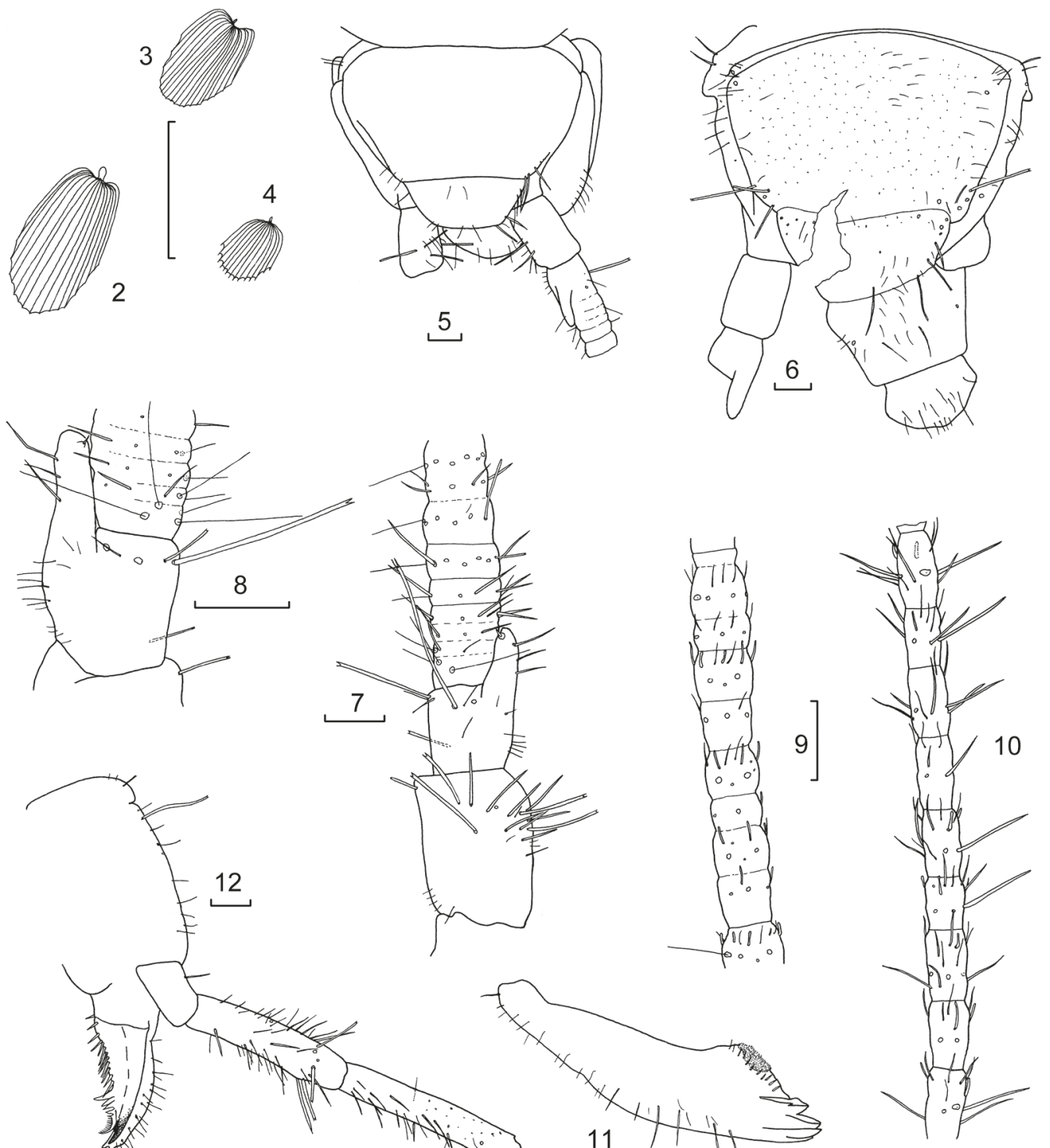

FIGURES 2-12 Lepidospora (Brinckina) maceveyi Smith \& Mitchell sp. nov., holotype $\sigma^{\lambda}$ unless indicated otherwise by specimen number: 2) scale from urotergite IV; 3) scale from urosternite $V_{;}$4) scale from femur PIII; 5) head, in alcohol (E108517); 6) head on slide; 7) left scape, pedicel and basal flagellomeres; 8) right pedicel and basal flagellomeres; 9) antennae, interval about half to two-thirds along flagellum; 10) antenna, most distal surviving interval; 11) mandible; 12) maxilla (palp incomplete). Scale bars $0.1 \mathrm{~mm}$. 


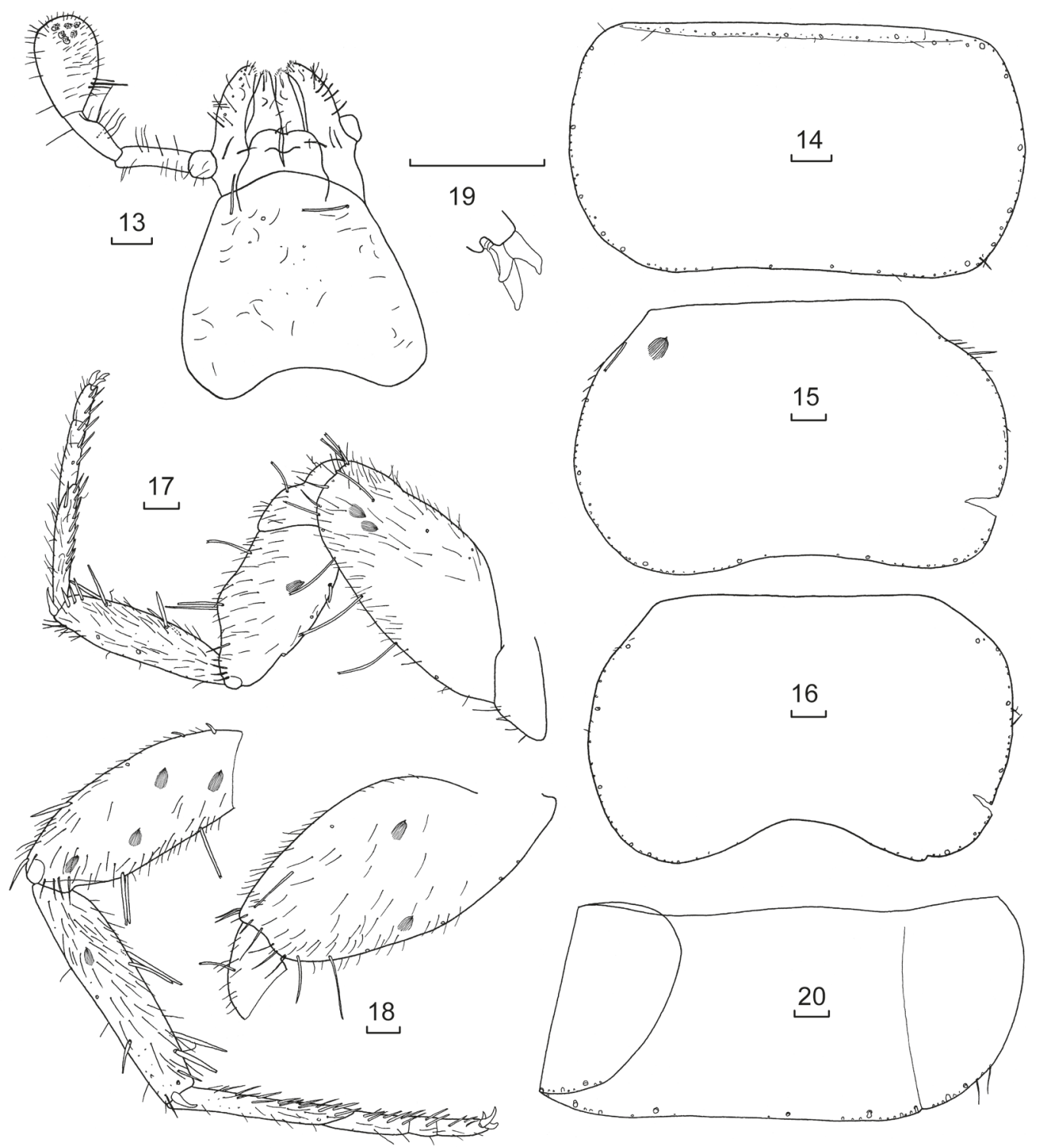

FIGURES 13-20 Lepidospora (Brinckina) maceveyi Smith \& Mitchell sp. nov., holotype ô: 13) labium; 14) pronotum; 15) mesonotum; 16) metanotum; 17) PII; 18) PIII; 19) pretarsus of PII; 20) urotergite V. Scale bars $0.1 \mathrm{~mm}$.

this scale has been dislodged from elsewhere and is just lying on the tibia.

Macrochaetae: Most simple, parallel-sided with distinct apical bifurcations but some on legs are stout and carrot-shaped usually without an apical bifurcation. Some of the longer parallel-sided macrochaetae, when slide mounted, show the same distortion reported in Smith et al. (2012) which is now believed to be an artefact caused by the Tendeiro medium.

Head: Almost as long as wide, not covered by prothorax at hind margin (Figures 5-6), prognathous, vertex with $1+1$ macrochaetae in postero-lateral corners as well as some smaller setae; five larger macrochaetae in antero-lateral corners adjacent to the antennal bases and 1+1 setae between the two groups; disc with numerous scattered small fine setae. - Clypeus with transverse row of four setae and two small fine setae between the middle setae. - Labrum with similar transverse row of setae, two of which are longer than the others. - Antennae elongate; scape of $\hat{\sigma}$ longer than wide, with several strong macrochaetae (Figure 7) both above and below; pedicel of $\delta$ with large thumbshaped apophyses on mediad face (Figures 7-8) about three times longer than wide, armed sub-apically with a short conical seta on the dorsal aspect, each apophysis reaching to about the third or fourth interval, but the sutures between the intervals can be difficult to see until the fourth or fifth; four trichobothria on the basal annulus and two each on the following five or six annuli; the eighth interval has two rings setae each with two trichobothria in the most distal ring, further subdivided into four annuli by the eleventh interval, each with a ring 
of setae and two trichobothria in the most distal annulus; intervals around mid-antennae (Figure 9) consisting of eight annuli with only a single trichobothrium in the most distal annulus; most annuli also with a ring of fine setae or perhaps basiconic sensilla subapically. The most distal surviving intervals (probably about twothirds antennae length) also with similar pattern but the arrangement of fine setae and basiconic sensilla distad of the ring of setae more scattered (Figure 10). The nature of these fine setae/sensilla is unclear on slide material, some are typical 'sausage-shaped' type C sensilla (see Adel, 1984) but other appear to be much longer and finer, almost indistinguishable from fine setae except that their ends appear to be rounded. - Mandibles (Figure 11) strong with well-developed molar and incisor regions and one apically bifurcate macrochaeta on the external face as well as a few longer simple setae. - Maxillae (Figure 12) of usual form, galea only surpassing length of lacinia by the two distinct apical papillae, lacinia well sclerotised with one strong apical tooth and a quite strong secondary tooth; pectinate prostheca not much shorter than lacinia with several lamellate processes and about 13 setae along margin; maxillary palp missing beyond third article in all specimens, appears to be fairly long, third article subapically appears to have two stronger setae. - Labium (Figure 13) longer than wide, ultimate article is about 1.3-1.4 times longer than wide with six papillae of usual type; the penultimate article with an oblique ring of longer stronger setae in the distal half.

Thorax: About one third $\mathrm{H}+\mathrm{B}$ and not wider than the abdomen, all nota of similar size; prothorax with obvious collar of six longer macrochaetae and many smaller setae, all nota with five strong submarginal macrochaetae along the lateral and the outer parts of the posterior margins, as well as shorter setae and setulae, the medial part of the posterior margin without macrochaetae; disc of nota with a few scattered setulae (Figures 14-16).

Legs typical for genus, PI missing in all specimens. Tibia L/W ratio of legs, PII 3.3-5.5, PIII 5.3; tarsi L/W ratio PII 8.9-10.8, PIII 14.2. PIII longer than PII. Legs quite elongate (Figures 17-18). Coxae with about five long macrochaetae spaced along the outer margin, with smaller macrochaetae more distally along this margin as illustrated, inner margin with two isolated macrochaetae well removed from the margin, margins and face covered with scattered fine setae and some scales; trochanter with one small macrochaeta and several smaller setae; femur with five stout curved carrot-shaped macrochaetae along leading margin, becoming longer distally, posterior margin with a macrochaeta proximally and two macrochaetae, on the distal bulge; tibia with two stout macrochaetae near the dorsal margin about one half and two thirds the distance along this margin, ventral margin with three tapered macrochaetae about one third along the margin and two longer macrochaetae at about three-quarters along the margin, three smaller, stout macrochaetae in a line near the distal margin, the usual distal spur is fairly short and smooth (without small subapical teeth); tarsus with four articles the basal one being almost as long as the other three together on both PII and PIII, each article with 1-7 paired stout carrot-shaped setae along its ventral surface depending on length of article; pretarsus (Figure 19) with two strong claws and a stout medial empodial claw, all claws in the holotype with unusual rounded apices but those of the paratype E108515 of normal pointed appearance.

Abdomen: Not much narrower than the thorax at its base. All urotergites wrap around the body without a sharp fold laterally. A suture between the tergite and the paratergites visible on II-VIII. Abdominal tergites I-VIII (Figure 20) on each side with three submarginal macrochaetae and one or two larger setae as well as smaller setae and setulae mediad of the suture, the medial region without chaetotaxy, and one submarginal macrochaeta plus two or three larger as well as some smaller setae and setulae laterad of the suture. Urotergite IX with reduced chaetotaxy; each side with one submarginal macrochaeta and two or three large setae as well as some smaller setae and setulae (Figure 21). Discs of all tergites with almost no scattered setulae, just a few on urotergite I and some in the antero-lateral corners of urotergites II-IV.

Urotergite X (Figures 22-23) with rounded posterior emargination, with $7+7$ strong pointed submarginal setae on the dorsal surface; ventrally the posterior corners point downwards; each of these extended corners armed with $8-10$ pegs as well as a few fine setae.

Urosternite I divided into a median sternum and two lateral coxites (Figure 24), the sternum without setae on the disc, the posterior margin with $1+1$ submarginal setae as well as some tiny setulae on the margin; posterior margin of the lateral coxites each with a seta insertion on the margin not far from the suture with the sternum, as well as some setulae. Urosternites II-VII entire (Figure 25), not divided into separate coxites and median sternum, each bearing $1+1$ styli and two apically bifurcate macrochaetae in the middle of the disc, and another subposteriorly on each side mediad of the base of each stylus; posterior margin with $1+1$ macrochaetae and some setulae, the margins laterad of the styli with a few setae and setulae. Eversible vesicles each with about four or five setae on the vesicle as well as a few setulae, on urosternites II-VI; VII with pseudovesicles. Urosternite VIII (Figures 26-27) also entire, without vesicles, with $1+1$ macrochaetae mediad of each stylus base (absent on right side of holotype), posterior margin slightly protruding with distinct concave region in the middle which also has $1+1$ submarginal macrochaetae as well as about six small marginal setulae (this concavity is quite abrupt in the holotype and paratype E108516 but more broad in paratype E108517), margins laterad of the styli with some small setulae and one or two small setae. Apical spine of the few styli still present all with two or three barbs (Figure 29). 

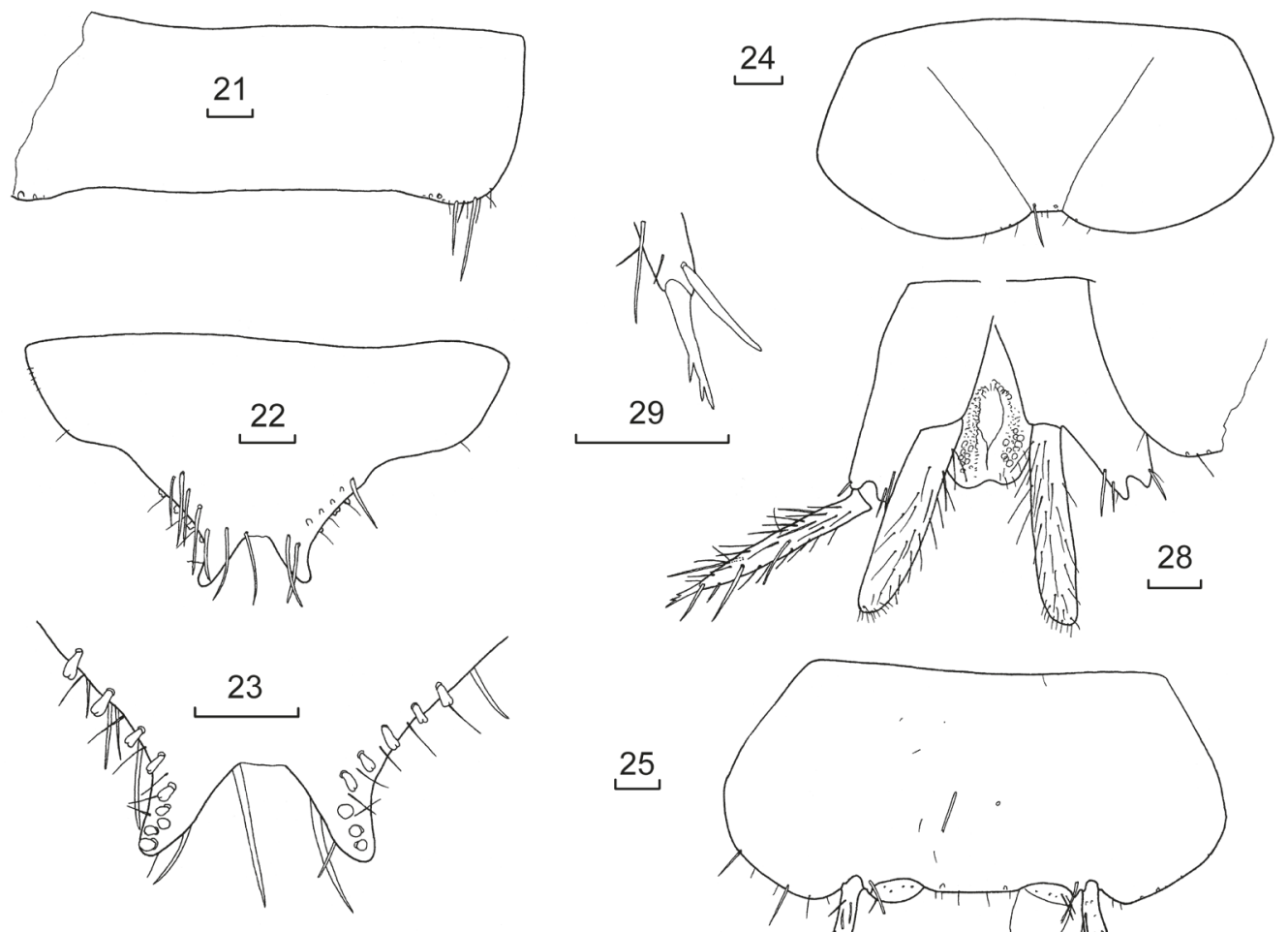

25
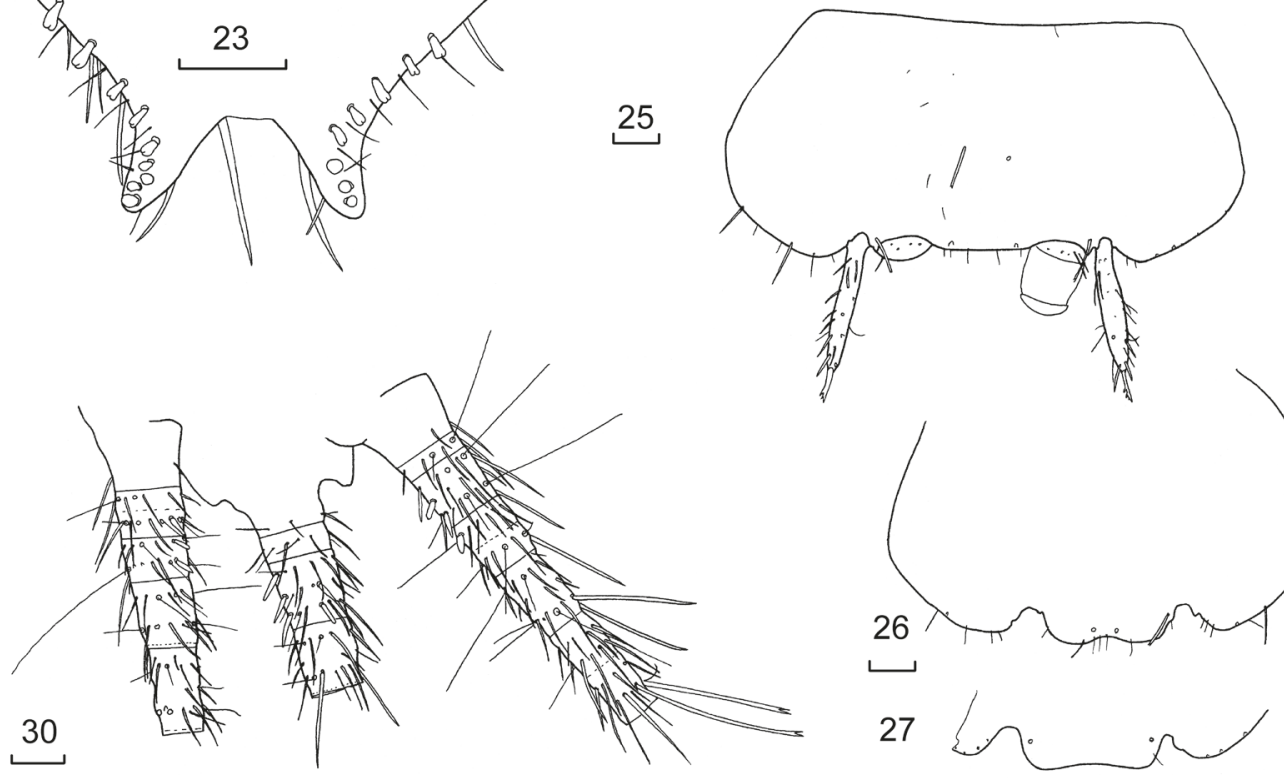

FIGURES 21-30 Lepidospora (Brinckina) maceveyi Smith \& Mitchell sp. nov., holotype ô unless indicated otherwise by specimen number: 21$)$ urotergite $I X$; 22 ) urotergite $X$, from above; 23 ) urotergite $X$, from below; 24) urosternite I; 25) urosternite III; 26) urosternite VIII; 27) urosternite VIII of paratype $\delta$ (E108517); 28) coxites IX, penis and parameres; 29) terminal spines of stylus IX; 30) base of terminal filaments, from below. Scale bars $0.1 \mathrm{~mm}$.

Urosternite IX (Figure 28) divided into separate coxites bearing styli and long parameres (L/W 4.7-5.0). Parameres reach to about one half the length of the styli, with several setae along their length and some small apical setulae. External process of coxites with one small seta and a setula; internal process with two setae near the inner margin. - Penis with longitudinal opening lined with hairs or lamellae, some glands visible basally.

Appendix dorsalis of $\hat{\partial}$ (Figure 30) without pegs on short basal division, dorsally with $2+3$ clearly modified spines (i.e. short, stout and with either a rounded or acute apex) on the longer third division, the following division without modified spines, each ring of setae or macrochaetae associated with short trichobothria, the ventral macrochaetae simple, not apically bifurcate, at least in the four divisions still intact; basal division of cerci (Figure 30) without modified chaetotaxy, following division with two rings of setae and trichobothria, each ring with a modified peg on the medial face of which the basal one has a sharp point, the distad is rounded, third division also with two rings of chaetotaxy with a rounded peg on the medial face of both rings, fourth division without modified chaetotaxy although the more basal macrochaeta, analogous to the peg, is somewhat thickened basally, the following division beginning to divide into two sections each with two rings of setae, the most distal ring in this division with stronger macrochaetae, those on the outer margin with strong bifurcations apically. 


\section{Female}

As for male except pedicel without apophyses (Figure 31 ); urotergite $\mathrm{X}$ trapezoidal with $1+1$ macrochaetae in the postero-lateral corners, medial indentation not wide (Figure 32), without pegs on ventral surface; terminal filaments presumably also without pegs. Coxites VIII and IX separated, subgenital plate rounded subtriangular with small submarginal setae distally and setulae scattered along the outer margins (Figure 33). Ovipositor with about 13 divisions, very slightly spindleshaped (i.e. wider in the mid region) and not particularly long, only surpassing the apices of styli IX by a few divisions. The apex of the anterior valves with a typical acute triangular projection, that of the posterior valves rounded with the typical region of hooked processes on the penultimate division; both with simple fine setae only.

\section{HABITAT}

All material examined was collected from two uncased mining exploration drill holes in the Hamersley Range. This range consists of an extensive series of connected rugged hills that run approximately $400 \mathrm{~km}$ across the Pilbara region of north-western Australia. The geology of the area is dominated by various iron formations, with the drill holes yielding Lepidospora (Brinckina) maceveyi occurring in banded iron formation. When weathered this formation develops vugs and voids that provide habitat for troglofauna.
The exact depth from which the animals were collected is unknown because they were collected from the walls of the drill holes with a net.

Other troglobitic species collected from the type locality EW0103 included Draculoides schizomids, Nocticola cockroaches, Prethopalpus oonopids and Cryptops centipedes. A large root mat occurring in the hole contained cockroaches and schizomids but no Lepidospora. Other troglobitic species at the paratype locality EWMS0006 were Ptinella beetles, Hanseniella symphylans and a centipede of the family Ballophilidae.

Mean annual rainfall at Paraburdoo airport $125 \mathrm{~km}$ to the south east of the type locality is $277 \mathrm{~mm}$, with $88 \%$ of the rain falling between January and June. The mean annual maximum temperature is $33.7^{\circ} \mathrm{C}$, with a mean monthly maximum temperature of $40.7^{\circ} \mathrm{C}$ in January. Despite the arid climate, data from elsewhere in the Pilbara suggest relative humidity below ground is maintained at close to $100 \%$ (Halse 2018).

\section{ETYMOLOGY}

The species is named for Dr Shane McEvey of the Australian Museum, who has provided much guidance to the second author and convinced him to develop a data base with a unique specimen number for each specimen collected. This data base has become central to our work on the Zygentoma and made so many other activities more efficient and traceable.

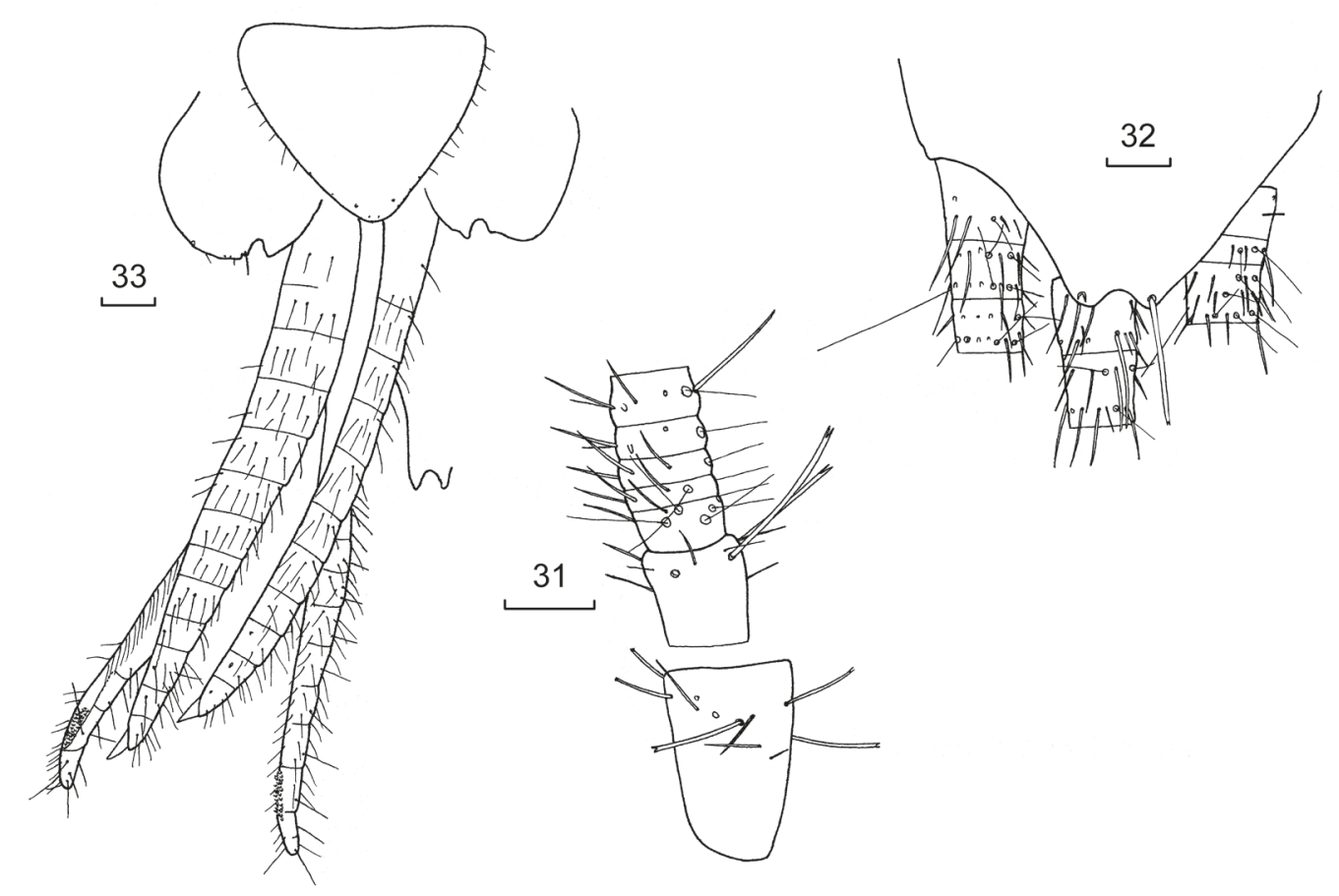

FIGURES 31-33 Lepidospora (Brinckina) maceveyi Smith \& Mitchell sp. nov., paratype o (E108515): 31) antenna, scape, pedicel and basal annuli; 32) urotergite $X$, from above; 33) subgenital plate, coxites IX and ovipositor. All scale bars $0.1 \mathrm{~mm}$. 


\section{DISCUSSION}

Morphologically the new species appears to be close to the other only other described Australian species of the Coletiniinae Lepidospora (Brinckina) relicta Smith \& McRae 2016, with both having an absence of larger setae over the disc of the nota, a medial region of all tergites lacking chaetotaxy and the presence of conules on the basal divisions of the median dorsal appendage. It does not appear to be as elongated as $L$. (B.) relicta although clearly would qualify as a troglobite based on its only known habitat.

The species will key to $L$. (B.) relicta using the key of Mendes (2002) combined with the emendation of Smith \& McRae (2016) but the species can easily be distinguished by the obvious concave region in the middle of the posterior margin of urosternite VIII of the males of the new species versus almost straight for $L$. (B.) relicta.

When describing $L$. (B.) relicta, scales were reported only on the coxae. The new species has scales on the femora as well as the coxae. Looking at the illustrations in Smith \& McRae (2016), it appears that there may be a small area of the femora without setae (smaller than in the new species) and it would probably be worth rechecking for scales in $L$. (B.) relicta before considering this to be a useful character to separate the species.

\section{CONCLUSION}

Molecular data confirm the close relationship between the Atelurinae and Coletiniinae, however there is relatively weak support for relationships among Atelurini, Atopatelurini and Coletiniinae. More genetic data is needed, and more taxa need to be sampled to get a firmer grasp of relationships.

\section{ACKNOWLEDGEMENTS}

Specimens of the described species were collected during fieldwork undertaken on behalf of Fortescue Metals Group. We would also like to thank the anonymous reviewers as well as Stuart Halse of Bennelongia, for their valuable comments on the manuscript.

\section{REFERENCES}

Adel, T. (1984). Sensilleninventar und sensillenmuster auf den Antennen von Thermobia domestica und Lepisma saccharina (Insecta: Zygentoma). Braunschweiger Naturkundliche Schriften 2: 191-217.

Escherich, K. (1905). Das System der Lepismatiden. Zoologica (Stuttgart) 43: 1-164. doi: 10.5962/bhl.title.7909.

Espinasa, L., Flick, C. and Giribet, G. (2007). Phylogeny of the American silverfish Cubacubaninae (Hexapoda: Zygentoma: Nicoletiidae): a combined approach using morphology and five molecular loci. Cladistics 23(1): 22-40. doi: 10.1111/j.1096-0031.2006.00127.x.

Espinasa, L. and Mendes, L.F. (2013). The first cavernicolous Nicoletiidae (Insecta: Zygentoma) from the United Arab Emirates. Journal of Cave and Karst Studies 75(2): 121125. doi: 10.4311/2011LSC0256.
Guzik, M.T., Austin, A.D., Cooper, S.J.B., Harvey, M.S., Humphreys, W.F., Bradford, T., Eberhard, S.M., King, R.A., Leys, R., Muirhead, K.A. and Tomlinson, M. (2010). Is the Australian subterranean fauna uniquely diverse? Invertebrate Systematics 24: 407-418. doi: 10.1071/IS10038.

Halse, S. A. (2018). Subterranean fauna of the arid zone. pp. 215-241 in H. Lambers (ed) The ecology of the Australian arid zone. Springer Nature, Basel. doi: 10.1007/978-3-31993943-8 9.

Halse, S.A. and Pearson, G.B. (2014). Troglofauna in the vadose zone: comparison of scraping and trapping results and sampling adequacy. Subterranean Biology 13: 17-34. doi: 10.3897/subtbiol.13.6991.

Irish, J. (1990). Phylogeny of the Lepismatidae (Thysanura), with a revision of the southern African genera. Unpublished Ph.D. thesis. Faculty of Science, University of Pretoria, 337 pp.

Joseph, G. (1882). Systematisches Verzeichniss der in den Tropfstein-Grotten von Krain einheimischen Arthropoden nebst Diagnosen der vom Verfasser entdeckten und bisher noch nicht beschriebenen Arten. Berliner Entomologische Zeitschrift 26(1): 1-50.

Kearse, M., Moir, R. and Wilson, A. (2012). Geneious Basic: An integrated and extendable desktop software platform for the organization and analysis of sequence data. Bioinformatics 28(12): 1647-1649. doi: 10.1093/bioinformatics/bts199.

Lanfear, R., Frandsen, P.B., Wright, A.M., Senfeld, T., and Calcott, B. (2016) PartitionFinder 2: New Methods for Selecting Partitioned Models of Evolution for Molecular and Morphological Phylogenetic Analyses. Molecular Biology and Evolution 34(3): 772-773. doi: 10.1093/molbev/msw260.

Lubbock, J. (1873) Monograph of the Collembola and Thysanura. The Ray Society, London, 276 pp. doi: 10.5962/ bhl.title. 11583

Machida, R.J. and Knowlton, N. (2012). PCR Primers for metazoan nuclear $18 \mathrm{~S}$ and $28 \mathrm{~S}$ ribosomal DNA sequences. PLoS ONE 7(9): e46180. doi: 10.1371/journal.pone.0046180.

Mendes, L.F. (1988). Sur deux nouvelles Nicoletiidae (Zygentoma) cavernicoles de Grèce et de Turquie et remarques sur la systématique de la famille. Revue Suisse de Zoologie 95(3): 751-772.

Mendes, L.F. (2002). Some new data and descriptions of thysanurans (Zygentoma: Nicoletiidae) from Central and Eastern Africa. Annales. Musée Royal de l'Afrique Centrale. Série in Octavo. Sciences Zoologiques 290: 87-127.

Miller, M.A., Pfeiffer, W. \& Schwartz, T. (2010) Creating the CIPRES Science Gateway for inference of large phylogenetic trees. Gateway Computing Environments Workshop (GCE), New Orleans, LA, USA. IEEE, 1-8. doi: 10.1109/GCE.2010.5676129.

Mitchell, A. (2015). Collecting in collections: a PCR strategy and primer set for DNA barcoding of decades-old dried museum specimens. Molecular Ecology Resources 15: 1102-1111. doi: 10.1111/1755-0998.12380.

Molero-Baltanás, R., Gaju-Ricart, M. and Bach de Roca, C. (2000). On the taxonomic use of the distribution pattern of the antennal asteriform sensilla in Neoasterolepisma and Tricholepisma (Insecta, Zygentoma, Lepismatidae). Pedobiologia 44: 248-256. doi: 10.1078/S00314056(04)70045-1.

Paclt, J. (1963) Thysanura. Fam. Nicoletiidae. Genera Insectorum 216e: 1-56. 
Ratnasingham, S. and Hebert, P.D.N. (2007). BOLD: The Barcode of Life Data System (www.barcodinglife.org). Molecular Ecology Notes 7: 355-364. doi: 10.1111/j.14718286.2007.01678.x.

Remington, C.L. (1954). The suprageneric classification of the order Thysanura (Insecta). Annals of the Entomological Society of America 47: 277-286. doi: 10.1093/aesa/47.2.277.

Ronquist, F., Teslenko, M., van der Mark, P., Ayres, D.L., Darling, A., Höhna, S., Larget, B., Liu, L., Suchard, M.A., and Huelsenbeck, J.P. (2012). MrBayes 3.2: Efficient Bayesian Phylogenetic Inference and Model Choice Across a Large Model Space. Systematic Biology 61(3): 539-542. doi: 10.1093/sysbio/sys029.

Smith, G.B. (2013). A new species of Heterolepisma from Barrow Island (Zygentoma: Lepismatidae). Records of the Western Australian Museum, Supplement 83: 229-240. doi: 10.18195/issn.0313-122x.83.2013.229-240.

Smith, G.B. (2015). New silverfish species (Zygentoma: Lepismatidae) from Barrow Island. Records of the Western Australian Museum 30: 98-131. doi: 10.18195/issn.03123162.30(2).2015.098-131.

Smith, G.B., Eberhard, S.M., Perina, G. and Finston, T. (2012). New species of short range endemic troglobitic silverfish (Zygentoma: Nicoletiidae) from subterranean habitats in Western Australia's semi-arid Pilbara region. Records of the Western Australian Museum 27: 101-116. doi: 10.18195/ issn.0312-3162.27(2).2012.101-116.

Smith, G.B. and McRae, J.M (2014). New species of subterranean silverfish (Zygentoma: Nicoletiidae: Atelurinae) from Western Australia's semi-arid Pilbara region. Records of the Western Australian Museum 29: 105-127. doi: 10.18195/issn.0312-3162.29(2).2014.105-127.

Smith, G.B. and McRae, J. (2016). Further short range endemic troglobitic silverfish (Zygentoma: Nicoletiidae; Subnicoletiinae and Coletiniinae) from north-western Australia. Records of the Western Australian Museum 31: 41-55. doi: 10.18195/issn.0312-3162.31(1).2016.041-055.

Smith, G.B., Mitchell, A., Lee, T.R.C. and Espinasa, L. (2019). DNA barcoding and integrative taxonomy of the Heterolepisma sclerophylla species complex (Zygentoma: Lepismatidae: Heterolepismatinae) and the description of two new species. Records of the Australian Museum 71(1): 1-32. doi: 10.3853/j.2201-4349.71.2019.1677.

Stamatakis, A. (2014). RAxML version 8: a tool for phylogenetic analysis and post-analysis of large phylogenies. Bioinformatics 30: 1312-1313. doi: 10.1093/ bioinformatics/btu033

Villesen, P. (2007). FaBox: an online toolbox for FASTA sequences. Molecular Ecology Notes 7: 965-968. doi: 10.1111/j.1471-8286.2007.01821.x.

Wygodzinsky, P. (1955). Thysanura. pp. 83-190 in B. Hanström, P. Brink \& Rudebeck, G. (eds) South African Animal Life, Vol. 2. AlmQvist \& Wiksells Boktryckeri AB, Uppsala.

Wygodzinsky, P. (1963). On J. Paclt's Nicoletiidae (Thysanura) in the "Genera Insectorum". Annals and Magazine of Natural History, Series 13, 6: 265-269. doi: 10.1080/00222936308651352.

MANUSCRIPT RECEIVED 23 DECEMBER 2020; ACCEPTED 19 JANUARY 2021. 